DOI 10.22455/2541-8297-2019-14-314-332

УДК 821.161 .1

\title{
Новые материалы о жизни и творчестве С.Д. Дрожжина. Проблемы изучения народного поэта
}

\author{
(C) 2019, М.В. Строганов
}

\begin{abstract}
Аннотация: В статье анализируется предпринятый в 1920 г. проект по изданию нового собрания стихотворений С.Д. Дрожжина - русского крестьянского поэта конца XIX - начала XX в., практически не привлекавшего внимание отечественных исследователей. Как устанавливается в ходе анализа, рукопись, хранящаяся в фондах мемориального дома-музея С.Д. Дрожжина в пос. Новозавидовский, содержит перечень стихотворений с комментариями бытового, текстологического и библиографического характера, которые позволяют дополнить известные сведения о жизни и творчестве Дрожжина, в том числе установить имена адресатов его любовной лирики. Данный источник впервые вводится в научный оборот, тем самым уточняются некоторые ключевые моменты, связанные с исследованием творчества «народных поэтов» в русской литературе. Подробная роспись включенных в рукопись текстов приводится в статье. Уточнение посвящений и датировок стихотворений восстанавливает важные моменты биографии поэта. Сравнение вариантов отдельных стихотворений Дрожжина, созданных в разные годы, ставит вопрос о квалификации их изменений. В отличие от конформизма, как мы обычно квалифицируем примиренческие позиции «интеллигентской» литературы, предлагается называть данное явление склонностью к компромиссам, в которой отразилось общественное поведение народной массы, обусловленное низким уровнем интеллектуального развития и неспособностью осмыслить истинные причины явлений.

Ключевые слова: С.Д. Дрожжин, народный поэт, текстология, комментарий, варианты

Информация об авторе: Михаил Викторович Строганов, д.ф.н., ведущий научный сотрудник, Институт мировой литературы им. А.М. Горького РАН, Москва, Россия. E-mail: mvstroganov@gmail.com

Цитирование: Строганов М.B. Новые материалы о жизни и творчестве С.Д. Дрожжина. Проблема изучения народного поэта // Литературный факт. 2019. № 4 (14). C. 314-332. DOI 10.22455/2541-8297-2019-14-314-332
\end{abstract}


Творчество Спиридона Дрожжина (как, впрочем, творчество всех русских крестьянских поэтов второй половины XIX - начала XX в.) лежит за пределами исследовательского внимания отечественного литературоведения. С тех пор как разговоры о пресловутой некрасовской школе в поэзии потеряли актуальность, а особенно с тех пор как на читателя и исследователя обрушилась литературная лавина новейшего времени, - ни Дрожжин, ни поэты его круга уже не привлекают к себе внимания. Интеллектуальный уровень этой литературы не выдерживает современной критики, которая снобистски жестко отворачивается от «исконно-посконной» поэзии Дрожжина, в самом деле не лишенной некоторой наивности. В свое время Р.М. Рильке вместе с Лу Андреас-Саломе посетил Дрожжина и пришел от него в восторг, но потом познакомился с интеллектуальным соседом Дрожжина - помещиком и литератором Н.А. Толстым, и наивный Дрожжин померк в его глазах ${ }^{1}$. Рильке искал «свою» Россию и нашел ее не в Дрожжине, а в Толстом, - разве это беда Дрожжина? - это ошибка Рильке. Так и в нашем случае: стоит только смело допустить, что не народные поэты не дотягивают до интеллектуального уровня современной критики, а, напротив, современная критика не владеет необходимым инструментарием для осмысления этого пласта культуры, - и всё встанет на свои места. Не надо только требовать от Дрожжина (и иже с ним) того же, что мы получаем от Мандельштама и Гиппиус. Надо принять его таким, каков он есть, и это даст нам понимание той большой низовой России, которая жила сама по себе, не слишком-то нуждаясь ни в Мандельштаме, ни в Гиппиус.

В настоящей публикации я пытаюсь вновь привлечь внимание научной общественности к этому весьма характерному явлению русской общественной жизни конца XIX — начала XX в., к творчеству народных поэтов, самой яркой фигурой среди которых был Дрожжин. В данном случае предметом анализа становится рукопись под названием «Варианты, заметки и примечания к Стихотворениям С. Дрожжина 1866-1904.-1907.-1920 гг. и последующих годов, сделанные автором вначале к приготовленному в 1920 году к печати $4<-$ му> издания <так!> полного собрания Стихотворений в 2-х томах, или 4-х». Эта рукопись хранится в фондах мемориального дома-музея С.Д. Дрожжина в пос. Новозавидовский. Она еще не привлекала к себе внимание, хотя содержит многие очень важные данные. Руко-

${ }^{1}$ Строганов M.B. Рафинированное и простонародное. Рильке и Андреас-Саломе в гостях у Дрожжина // Лабиринт: журнал социально-гуманитарных исследований [Электронный журнал]. 2016. № 3/4. C. 71-85. URL: http://journal-labirint.com/wpcontent/uploads/2016/09/Stroganov.pdf (дата обращения 21.11.2019). 
пись представляет собой переплетенную тетрадь в твердой обложке, в которую Дрожжин записывал порядок стихотворений и делал к ним те или иные комментарии. Все записи сделаны чернилами, в двух случаях появляются карандашные пометки, которые, судя по почерку, принадлежат Л.А. Ильину, известному исследователю творчества поэта, долгое время бывшему директором музея Дрожжина (далее при ссылках на рукопись мы указываем только номера листов) ${ }^{2}$.

Как известно, при жизни Дрожжина вышло три более или менее репрезентативных издания его стихотворений ${ }^{3}$. В 1920 г. (и позднее) он готовил и пытался издать четвертое издание собрания своих стихотворений, о чем неоднократно говорил в дневниках, но это предприятие не удалось, в первую очередь потому, что новая пролетарская власть видела в крестьянине мелкого частного собственника с чуждой ей идеологией. Она еще соглашалась праздновать прошлые заслуги старого поэта, но давать ход его новым начинаниям не собиралась.

Дрожжин же, продолжая надеяться на успех начинания, готовил издание. Сохранившая тетрадь содержит перечень стихотворений 1876-1882 гг, которые он собирался включить в четвертое издание. Этот перечень сопровождается дополнительной информацией: точная датировка стихотворения - либо по памяти, либо по датированным рукописям; указание на первые публикации и музыкальные переложения стихотворений (иногда ошибочные, но в любом случае полезные для комментариев); приведение вариантов текста, большей частью неопубликованных; сообщение отдельных биографических сведений, помогающих понять жизненный и творческий путь поэта в целом.

Во-первых, мы узнаем ряд фактов биографии Дрожжина, известной нам - за отсутствием биографических документов - преимущественно по его автобиографии, которую, как известно, он весьма существенно правил применительно к текущему времени и обстоятельствам. Мы выясняем настоящую фамилию девушки, которую

2 Благодарю заведующую домом-музеем С.Д. Дрожжина Е.В. Павлову за помощь в работе с этим материалом.

${ }^{3}$ Дрожжин С.Д. Стихотворения. 1866-1888. С записками автора о своей жизни и поэзии. СПб.: Изд. М.О. Вольф, 1889; Дрожжин С.Д. Стихотворения. 1866-1888. С записками автора о своей жизни и поэзии. 2-е изд. СПб.: Изд. М.В. Клюкина, 1894; Дрожжин С.Д. Стихотворения 1866-1888. Т. 1. 3-е изд. М.: Тов. И.Н. Кушнерёв и К을 1907. 
Дрожжин полюбил, когда в 1873 гг. служил лакеем у И.К. Владыкина, владельца усадьбы Алексейцево Романо-Борисоглебского уезда Ярославской губернии в 26 верстах от Ярославля. Дрожжин указывает в нашей рукописи, что этой девушке, Е.Н. Кулаковой, посвящены «Романс» (27 августа 1873; л. 16), «Воспоминание» (17 апреля 1874; л. 16об.) и «Едва вечерняя звезда» (май 1875; л. 21об.). Девушка была дочерью женщины, которая служила няней у того же помещика Ивана Константиновича Владыкина ${ }^{4}$, и приезжала в летние месяцы к своей матери погостить. Любовная склонность молодых людей была взаимной, но мать девушки потребовала, чтобы Дрожжин нашел «себе приличную должность» (автобиография 1923 г.) $)^{5}$. Однако пока молодой человек занимался этими поисками, любовь прошла:

Невеста моя тогда жила на квартире и шила на машинке (она была портниха). Я изредка ходил к ней и приносил книги, но между нами не было уже прежней теплоты и искренности; дело в том, что я, не видя никакой перемены и улучшения в моей труженической жизни, стал колебаться в возможности счастья в предполагаемом браке; поэтому, когда в последний раз совершенно случайно встретился с нею на улице, то она, взглянув на меня, горько улыбнулась и сказала:

- Вас нынче просто нельзя узнать!

— Да, — ответил я, — к несчастью, я уже стал не тот, каким вы меня знали прежде ${ }^{6}$.

Дрожжин уехал в Петербург, а девушка вышла замуж за другого. В автобиографических записках Дрожжин писал: «Проездом через Москву зашел я к матери бывшей моей невесты и узнал, что девушка вышла уже замуж. Горько мне это было! С воспоминанием о потерянном счастье, после 28 -дневного пути < ..> приехал я в Ташкент» ${ }^{7}$.

В сборнике «Гусляр» стихотворение «Едва вечерняя звезда» («Как полуночная звезда») имеет посвящение В.М. Кузнецовой ${ }^{8}$, а в данной рукописи - Е.Н. Кулаковой. Поскольку и в издании Дрожжина 1907 г. стихотворение посвящено Е.А. К-вой ${ }^{9}$, следует

${ }^{4}$ Поэт-крестьянин Спиридон Дрожжин в его воспоминаниях. 1848-1884 гг. // Русская старина. 1884. T. XLIV. Октябрь. С. 112.

5 Дрожжин С.Д. Собрание сочинений: В 3 т. / Общ. ред. М.В. Строганова. Тверь, 2015. Т. 3: Воспоминания. Дневник. С. 139.

${ }^{6}$ Воспоминания 1905 г. // Там же. С. 101.

7 Там же. С. 102.

8 Дрожжин С.Д. Гусляр: Неопубликованные произведения / Предисл., подгот. текста и примеч. Е.В. Павловой, М.В. Строганова. М., 2018. С. 101.

9 Дрожжин С.Д. Стихотворения 1866-1888. Т. 1. 3-е изд. С. 201. 
считать, что это одно и то же лицо, но одна из фамилий девичья, а другая мужняя. Фамилию, которую находим в «Гусляре», следует считать фамилией мужа, а более часто повторяющуюся - девичьей. В этом особенно убеждает тот факт, что среди стихотворений Дрожжина 1883 г. есть стихотворение «Листок. Памяти Лизы Кулаковой», и здесь уже сомнений быть не может: инициал Е. в нашей рукописи явно обозначает Елизавету, а интимность посвящения указывает, что Кулакова — это ее девичья фамилия.

Вторая героиня любовной жизни Дрожжина, имя которой мы можем теперь назвать, — это Мария Балкашина. В нашей рукописи находим такую запись: «Марии. I и II» (30 и 31 августа 1877); «Написаны после долгой разлуки с нею и встречи в табачном магазине на Невском пр., куда она зашла после гулянья по иллюминации по случаю именин Александра II» (л. 26). И хотя среди стихотворений Дрожжина 1877 г. нет цикла из двух стихотворений с таким названием, но два стихотворения, не составляющие цикла, вполне отвечают описанному настроению. Первое:

Опять давно погибшую

Тебя я узнаю,

Так искренне любившую

Красавицу мою;

Опять твой взор ласкающий

Мне сердце взволновал,

И пламень угасающий

Сильнее запылал ${ }^{10}$.

И второе стихотворение:

На склоне дней

Опять любовь

В груди моей

Волнует кровь,

Опять, опять

Душой страдать

И тосковать

Хоть не тоской

Любви былой...

Уж жизни той

10 Дрожжин С.Д. Собрание сочинений: В 3 т. / Общ. ред. М.В. Строганова. Тверь, 2015. Т. 1: Стихотворения. 1867-1894. С. 112. Ср.: Дрожжин С.Д. Гусляр. C. 172 . 
Возврата нет,

Загублен мой

Душистый цвет,

Средь моря бед

Мои мечты

О днях былых

Пережиты;

Лишь горький стих

Звучит о них,

Звучит о той

Любви былой ${ }^{11}$.

Ясно, что при жизни своей жены Дрожжин не хотел лишний раз напоминать о былых увлечениях, но после ее смерти открыто называет имена своих прежних возлюбленных. В результате у стихотворения «После разлуки» появляется открытое посвящение Марии Балкашиной (16 июня 1877; л. 28), которое ранее печаталось с посвящением «Марии Б-ой»:
Отчего так твои щечки
Побледнели, милый друг,
Отчего горячий пламень
На устах твоих потух?
Отчего краса поблекла,
Расскажи мне, отчего
Веет холодом осенним
Так от взора твоего?
Оттого, что я с тобою
Не видалась много лет,
Во слезах потухли очи
И пропал румянца след;
Оттого краса поблекла,
Что, тоскуя и любя,
За немилым старым мужем
Вспоминала я тебя ${ }^{12}$.

Совершенно очевидно, что именно с этой женщиной связан и маленький цикл из двух стихотворений «К Марии» (1866-1868), который появился в печати в издании 1907 г.: первое «Когда ты детские

\footnotetext{
${ }_{11}^{11}$ Дрожжин С.Д. Собрание сочинений. Т. 1. С. 113.

12 Там же. С. 123.
} 
свои» и второе «Маша, Маша, что скажу я» ${ }^{13}$. Для нового издания Дрожжин предполагал дополнить его еще девятью стихотворениями (л. 5об.), но текст их он не сообщил, а в рукописях он неизвестен. Именно эту женщину Дрожжин упоминает в воспоминаниях 1905 г. и в автобиографии 1923 г.:

С этих пор я с жаром принялся за стихи. Боже мой, как сильно в то время верилось и любилось! И вот как-то раз зимою по окончанию торговли пришел я вечером в хозяйскую квартиру, где увидел прелестную черноглазую девочку лет тринадцати; она, как после оказалось, была племянницей нашей служанки и пришла к ней в гости. Звали ее Машей. Маша была глубоко несчастлива, жила с отцом и мачехой. Всей силой моей души привязался я к этой девушке, часто перечитывал с ней моих любимых авторов, а также написал и посвятил ей несколько стихотворений ${ }^{14}$.

Чтение и любовь 14-летней красавицы Марии, родной племянницы хозяйской служанки, снова пробудили во мне стремление к поэтическому творчеству, и я с жаром принялся за писание стихов ${ }^{15}$.

Самый обстоятельный и конкретный рассказ об этой девочке мы находим в первой автобиографии Дрожжина, опубликованной в «Русской старине» за 1884 г.:

Зимою 1865 года одним вечером, придя на квартиру хозяина на ночлег, я увидел прелестную темноглазую девочку лет тринадцати; она сразу приковала к себе мое внимание по-детски задумчивым, но необыкновенно умным и симпатичным личиком. Мы тут же скоро познакомились и сделались друзьями. Маша, как звали эту девочку, была племянница хозяйской служанки и дочерью от первой жены одного петербургского мещанина, артельщика Михаила Балкашина. Она была, как я узнал впоследствии, обучена грамоте и глубоко несчастлива. Мачеха ее била и ненавидела. Я привязался к этому ребенку всею силою души, какая может проявиться у семнадцатилетнего юноши-идеалиста, и с 1866 года написал и посвятил ей множество своих стихотворений ${ }^{16}$.

Дрожжин не упоминает встречу с Марией Балкашиной в июле 1877 г.: это было его глубоко затаенное переживание, которое

\footnotetext{
13 Там же. С. 35.

14 Дрожжин С.Д. Собрание сочинений. Т. 3. С. 29.

15 Там же. С. 135.

16 Поэт-крестьянин Спиридон Дрожжин в его воспоминаниях. 1848-1884 гг. Октябрь. С. 93.
} 
отразилось только в стихах, без указания имен. Но для нас восстановление имен адресатов открывает внутренний мир человека.

И еще один адресат. Стихотворение «Пой мне, друг, пока поется» имеет посвящение М.В. Флериной. При этом указано: «Мария Васильевна Флерина. Дочь нашего священника Василия Ивановича» (л. 35об.). Этого священника Дрожжин (не называя его по имени) упоминает во всех автобиографических записках, приводя дневниковую запись от 31 мая 1884 г.:

В моей деревенской библиотеке имеются почти все журналы, в которых я участвовал, и до 300 томов сочинений историко-литературных и собрания моих любимых авторов. Библиотека эта составлялась мною более 20 лет; ею у меня теперь пользуются все, начиная со священника, учителя и кончая молодым любознательным крестьянином, желающим «почитать книжечку». Потребность между грамотными крестьянами «почитать книжечку, в которой бывает больно хорошо написано», с каждым годом увеличивается - это радует и бодрит мою душу... ${ }^{17}$

По имени же он упоминает его только в самых ранних воспоминаниях (и не без иронии):

В 12 часов пришел священник отец Василий <Флерин> и мой бывший учитель дьячок Василий Ефимович Воскресенский, отслужили в избе молебен Илье пророку. Просили водки, но ее у нас не оказалось, а купить было не на что, и духовные пастыри ушли недовольными ${ }^{18}$.

В издании 1894 г. посвящение обозначено: М.В. Ф...ной ${ }^{19}$. Датировано стихотворение в нашей рукописи более точно, чем в печатных изданиях: 2 июля 1881 г. Во всех изданиях первая строка стихотворения читалась так: «Пой, дитя, пока поется». Но в 1920 г. поэт слегка изменяет первую строку:

Пой мне, друг, пока поется,

Без тоски тяжелой,

Быстро время пронесется

Юности веселой;

17 Дрожжин С.Д. Собрание сочинений. Т. 3. С. 115-116. Ср. также: Там же. C. $55-56,152$.

18 Поэт-крестьянин Спиридон Дрожжин в его воспоминаниях. 1848-1884 гг. Ноябрь. С. 331.

${ }^{19}$ Дрожжсин С.Д. Стихотворения. 1866-1888. 2-е изд. С. 215. 

С ней минует радость-счастье,
Ты узнаешь слезы
И увянешь, как в ненастье
Цвет душистой розы ${ }^{20}$.

Но с 1881 до 1920 г. прошло сорок лет, и за это время Мария Васильевна не только перестала быть дитятей, но наверняка «увяла, как в ненастье цвет душистой розы», так что упоминать об этом было нетактично.

Есть в рукописи и некоторые другие материалы, которые вносят уточнения в биографию поэта и конкретизируют наши знания о его окружении и связях. Мы не можем описать их в настоящем сообщении во всей полноте, для нас сейчас важнее отметить направление этой работы.

Все эти лица не были замечены в истории, от них не осталось каких-либо документальных свидетельств. И, казалось бы, можно было бы просто обойтись указанием: девушка, которую любил Дрожжин, девушка, с которой он был знаком в ранние годы жизни в Петербурге, а потом встретил по возвращении туда. Вроде бы и достаточно. Однако вполне естественно, что появление у этих «девушек» личных имен делает рассказ о жизни и творчестве Дрожжина более конкретным и понятным, вместо туманных некто появляются конкретные Лиза и Мария.

Всего в данной рукописи описано 223 стихотворения. Согласно этой тетради, из стихов, которые были написаны в 1866-1869 гг., когда молодой автор только начинал и работал еще не вполне профессионально, в новое собрание он собирался включить 18 стихотворений: «Мои песни (Нет, мне не весело ничуть)», «Годы мчатся за годами», «Песня (Рано солнышко)», «Забота матери», «Жизнь, улыбнися хотя на мгновенье», «Спит село, объятое (Звездочка)», «Измена», «Песня (Светит весело)», «Сократ Басков», «С травою вместе подкошенный», «Тоска неутолимая», «Ожидание», «Песня (Ах, зачем весной)», «К Марии» (1 и 2 песни цикла, в новое издание предполагалось включить 3-11 песни), «Из Т. Шевченко (И день пройдет, и ночь пройдет)», «Песня (Расплетися, коса русая моя)», «Завещание. Вольный перевод из Т.Г. Шевченко», «Песня (Много с детских лет)».

\footnotetext{
${ }^{20}$ Дрожжин С.Д. Собрание сочинений. Т. 1. С. 174.
} 
1869 г. - 8 стихотворений: «Песня работника (на мотив Томаса Гуда)», «Летняя ночь в деревне», «О, горюшко-горе», «Так грустно мне, как погляжу», «Песня (Как увижу тебя)», «Старому другу (В чужом далеком городе)», «У чужих людей не знаю», «Песня (По дороге вьюга снежная)».

1870 г. - 14 стихотворений: «Песня (Ты душа ль моя)», «Песня (Что на поле весной)», «Я вас люблю, младые девы», «Летом рано солнце красное», «Молитва (К тебе с горячею любовью)», «Песня (В поле непогода)», «Дума пахаря», «Как сижу с тобой», «Много мыслей благородных», «Песня (Сердцу больно)», «Утро в лесу», «Кузнец и его сын», «Дорога жизни (Пусть трудна моя дорога)», «Песня (Быстро прокатилося)».

1871 г. - 11 стихотворений: «На память прошлых грустных лет», «Жница», «Песня (Не сосенка во сыром бору)», «Родина», «Лето красное миловалося», «Песня про горе добра молодца», «Урожай», «В простой телеге деревенской», «Песня (Ах, ты жизнь моя)», «Недопетая песня», «Пропадай ты, жизнь бездольная».

1872 г. - 11 стихотворений: «Песня про солдата», «Меня гнетут и давят цепи», «Жалобы мастерового», «Песня (Со кручинушки добрый молодец зашатался)», «Песня (Что, девица, с тоской)», «Иду я полем, трава зеленеет», «Сон малютки», «Песня (Полюбил тебя)», «Серенада (посв. В.К. Владыкиной)», «Песня (Не с мороза травушка)», «К соловью».

1873 г. - 8 стихотворений: «Во сне ты мне, милая, снилась», «Прощание», «Дайте мне и меч, и лиру», «Песня (Как листок оторван)», «Рабочая песня», «Разбитые гусли», «Романс (Е.Н. Кулаковой)», «Песня (Пришло времечко)».

1874 г. - 7 стихотворений: «Вот песни-думы огневые», «Песня (Ах, прошла весна)», «Воспоминание (Е.Н. Кулаковой)», «Песня (Был я молод)», «Песня (Ах, что, травушка)», «Малороссийская мелодия», «Песня (Ночка темная, ночка звездная)».

1875 г. - 38 стихотворений: «Горе девушки», «Песня (Ах, уж я ль, млада-младенька)», «Песня (Скучно-грустно жить на свете молодцу)», «Песня (На дворе темно и вьюга)», «Песня (Как поток бежит)», «Прощайте, родные поля и леса», «Песня (Много звезд сияет в небе)», «Песни с чужой стороны. I, II и III», «Песня швей», «На всей на вольной волюшке», «Жизнь прожи́та», «Моя муза», «Из песен работников», «Песни из далекого края. I и II», «Сон труженика», «Нет больше песен у меня», «Из-за леса над селом», «Склонися, девица», «В страду», «Н.А. Некрасову», «Песни рабочих. I и II», «Песня (Хорошо весной)», «Как сошлися мы с тобою», «Голубка 
и стрелок», «Песня (Ах ты, милый мой)», «Е.Н. Кулаковой. Едва вечерняя звезда», «Он был поэт, его значенья», «Песня (Полетать бы пташечке)», «В школе», «Песня (Что не ветер-ветерок)», «На тройке», «Татарская песня», «Как песню запою я», «Прости, когда моя кручина», «Сельская идиллия (подражание А.В. Кольцову)», «Песня» (Ах, о чем ты, ласточка), «Песня (За рекой село есть знакомое)», «Без довольства я доволен», «Вдова (Рассказ)».

1876 г. - 7 стихотворений: «Песня (Хороша ты, душа, красна-девица)», «Две поры (Н.В. Верещагину)», «Над цветами и травою», «Душа болит, душа тоскует», «Швея», «Сбросил бы с плеч я кручину», «Тоска по родине».

1877 г. - 20 стихотворений: «Как жалок цветок полевой», «Н.А. Некрасову (по прочтении его «Последних песен»)», «Песня (Что так жалобно ты, кукушечка)», «В крестьянской семье», «Песня (Много пташек залетных весною)», «Монолог», «Марии. I и II», «Песня (Ax, когда бы лето да не уходило)», «Птички поют голосисто (В деревне)», «И.З. Сурикову», «Песня (Ой, печаль-тоска)», «Смерть коня-пахаря», «Песня (Ах, пойду я)», «Вечная память», «Осенью», «Неудача», «На смерть Н.А. Некрасова. І. У гроба. II. Зачем эти клики военных побед. III. Одумал ты думу, одумал, родной. Причитание народа. IV. Нет, ты не умер, ты живешь. V. Похороны), «Песня (Если бы молодцу)», «Песня (Соберитеся вы, подруженьки)», «После разлуки (Марии Балкашиной)».

1878 г. - 20 стихотворений: «Ровнюшка», «Шумит ли лес, гремит ли гром», «Грусть молодой крестьянки», «Не сумею горя высказать словами», «Пряха», «Песня (Ты запой мне весной)», «Горе лютое», «На пути (А.Н. Пешковой)», «Детские годы», «Песня (Пролетело лето красное)», «Поэту», «Вот знакомый старый дом», «Звезда», «Весной», «Птицы», «Всё кругом покрыто мглою», «Домовой (С.А. Бердяеву)», «И.З. Сурикову», «Проходят лучшие годы», «На новый 1879 год».

1879 г. - 10 стихотворений: «Сын полка (Рассказ солдата)», «Мы весною друг друга узнали», «Честным порывам дай волю свободную», «Грозные тучи нависли», «Катится Волга, родная река», «Праздничной зимней порой», «Я пел всегда, когда поется», «Узник», «Весна-красна опять пришла», «Прошла пора любви и наслажденья».

1880 г. - 18 стихотворений: «Застольная песня (П.А. Соловьеву-Несмелову)», «Дуняша», «К песне», «Пчелы (Легенда)», «Привычно солнышко с небес», «Прозрачное облачко тает», «Памяти Н.А. Некрасова», «24 апреля 1880 года (Памяти И.З. Сурикова). 
I-IІ», «Привал на Волге (И.Е. Репину)», «Песня», «Спит трава, росой покрытая», «По вершине лесной», «Отдых крестьянина (Памяти дедушки Степана Степановича)», «Песня (По каменьям течет реченька)», «В зимний день», «Утром», «Тяжелый крест мне дан судьбой (С.А. Барашкову)».

1881 г. - 18 стихотворений: «Когда в избушке при огне», «Молитва матери», «Отрывок. Вот и лето миновало», «Народному певцу», «Федя», «Памяти А.С. Пушкина», «Вечер», «Кругом прозрачной пеленою», «На пашне», «На Волге», «Песня (Не буди ты в груди)», «Деревенская идиллия (Памяти сына)», «Пой мне, друг, пока поется (М.В. Флериной)», «Летом», «Над колыбелью», «Песня (Что грозой)», «Когда красавица стояла», «Песня (Не шуми ты, злая буря, за окном)».

1882 г. - 14 стихотворений: «В воздухе птичка поет», «Ой, как тесен мир без песен», «Колыбельная песня (Моему сыну)», «Бурное море», «На работу», «Сказка-быль», «Птичка-синичка», «Другу», «В дороге», «В избе», «Петербургское утро», «Приход весны», «Куда идти, какой дорогой», «Сон».

Это, конечно, далеко не все стихотворения, которые были созданы Дрожжиным в данный период. Старый поэт хорошо чувствовал политическую конъюнктуру и не включил в новое собрание ни стихотворение «Скобелев (Едва ли выразит певец)» (1882), написанное на смерть М.Д. Скобелева, ни поэму «Отрок» (1882) - об основании Юрьева Отроча монастыря. В некоторых случаях Дрожжин руководствовался и собственно эстетическими (или даже вкусовыми) критериями, объяснить которые мы не имеем возможности. В следующей части нашей публикации мы обратимся только к новым текстологическим материалам, которые содержит описываемая рукопись, поскольку они указывают возможные пути дальнейшего изучения такого рода литературы. Вообще Дрожжин приводит варианты текста к целому ряду стихотворений: «Годы мчатся за годами», «Забота матери», «Летняя ночь в деревне» «Дума пахаря», «Как сижу с тобой», «Песня. Сердцу больно», «Дорога жизни (Пусть трудна моя дорога)», «Недопетая песня», «Пропадай ты, жизнь бездольная», «Во сне ты мне, милая, снилась», «Песня. Ночка темная, ночка звездная», «В школе», «Поэту», «Всё кругом покрыто мглою», «Честным порывам дай волю свободную». Однако мы опишем не все эти стихотворения, а только наиболее показательные из них, в которых Дрожжин пытался сформулировать свою общественно-политическую позицию и которые - вследствие этого - зафиксировали либо неумение определенно и точно выразить свою позицию (идеологиче- 
скую и литературную слабость поэта), либо сознательное изменение ее под влиянием внешних обстоятельств (конъюнктуру).

Уже первое стихотворение в нашей рукописи «Мои песни» сопровождается характерным комментарием Дрожжина: «Написано в Петербурге между 1866-1869 гг. В первый раз напечатано: “Русская старина” 1884 в “Автобиографии”. Затем вошло во все последующие издания Стихотворений и ставилось мной всегда первым в начале их. В бумагах сохранилось несколько вариантов». Далее Дрожжин приводит вариант, опубликованный в «Русской старине»:

Нет, мне не весело ничуть, Когда в измученную грудь Нисходит на мгновенье

Святое вдохновенье,

Сжигает мой пытливый ум

Огнем заветных горьких дум

Иль песнею свободной

С молитвою народной.

Они звучат в устах моих,

И каждый звук, и каждый стих,

Души моей созданье,

Приносит мне страданье.

Таков удел поэту дан:

Бушует жизни океан,

А он, отваги полный,

В ее стремится волны ${ }^{21}$.

Вслед за этим текстом Дрожжин приводит варианты стихов, которые сохранились в рукописи и отражают раннюю редакцию произведения (эти вариативные стихи мы для наглядности выделяем курсивом):

Как мне хотелось бы уснуть,

Когда в измученную грудь

В часы отдохновенья

Святое вдохновенье

21 Поэт-крестьянин Спиридон Дрожжин в его воспоминаниях. 1848-1884 гг. Октябрь. С. 94-95. 
Тревожит мой незрелый ум

Унылой музыкою дум

И песней невеселой

О долюшке тяжелой.

И я от них готов бежать

Куда-нибудь, чтоб не слыхать

Унылых песен звуки

И спрятаться от муки (л. 2).

Для понимания дальнейшего развития этого художественного замысла напомним окончательную редакцию стихотворения, опубликованную в 1894 г. и подтвержденную в 1907 г.:

Нет, мне не весело ничуть, Когда в измученную грудь На краткое мгновенье Нисходит вдохновенье, Тревожит мысль мою и ум Огнем заветных, чистых дум Иль песнею свободной Как гул толпы народной. И песнь звучит в устах моих; В ней каждый звук и каждый стих Души моей созданье, Приносит мне страданье.

Таков бестрепетный поэт:

Пред ним бушует море бед, А он, отваги полный, В его стремится волны ${ }^{22}$.

Мы видим напряженные попытки Дрожжина овладеть художественной темой. На самом раннем этапе герой стихотворения мучается тяжелыми думами о «долюшке тяжелой» и хочет бежать от этих дум, чтобы «спрятаться от муки». Редакция «Русской старины» изображает другого поэта: хотя «святое вдохновенье» приносит ему страдание, но во имя правды поэт продолжает творить. И эта идея сохраняется в редакции 1894 г., разница в ином. В «Русской старине» душа поэта мучилась «песнею свободной / С молитвою народной». В редакции же 1894 г. вместо «молитвы народной» появляется более политизированный «гул толпы народной».

${ }^{22}$ Ср. варианты: Ст. 10: И каждый звук и каждый стих. Ст. 13: Таков всегда иной поэт (Дрожжин С.Д. Стихотворения. 1866-1888. 2-е изд. 1894. С. 85). 
Стихотворение «Песня работника (на мотив Томаса Гуда)» в первых публикациях выглядело так:

К чему эти слезы с тоской безотрадной

И думы во мраке ночей,

Мне нужно работать весь день безустанно

Для родины милой моей.

Пока я способен на каждое дело

И честно могу потрудиться, -

Давайте работы! ведь грубое тело

Для жизни другой не годится.

Давайте работы! Здоров я и молод,

В борьбе, как булат, закален.

Давайте мне со́ху, лопату иль молот, Я с детства к труду приучен... ${ }^{23}$

Далее Дрожжин пишет: «В одной из рукописей этого стихотворения после первого куплета есть следующие», - имея в виду, что 5-12 стихи имели другой текст, и сообщает бытовые условия его создания: «Написано под впечатлением долгого скитальчества, голодания и безработицы». Вот эта ранняя редакция:

К чему эти слезы с тоской безотрадной

И думы во мраке ночей?

Мне нужно работать весь день безустанно

Для родины милой моей.

Давайте работать! Не мрачные лица

Пускай я увижу тогда,

А бодрых отцов и детей вереницы

Грядущих героев труда.

Когда же над Русью вражда разгорится,

Готов я за родину-мать

С врагами народа великого биться

И жизнь всю до капли отдать (л. 7).

Тут же Дрожжин добавляет, что стихотворение не вошло в издания Стихотворений 1866-1888 гг. 1889 и 1894 гг. и впервые появилось в другой редакции в ряде изданий. Вот этот окончательный текст:

23 Поэт-крестьянин Спиридон Дрожжин в его воспоминаниях. 1848-1884 гг. Октябрь. С. 101. 
Пускай я не знаю минуты отрадной, Пусть тучи висят надо мной -

Я буду работать и жить постоянно Для блага отчизны родной.

Давайте работы! Я молод душою, И силы немало во мне, Давайте хоть со́ху, хоть грабли с косою, Топор или цеп на гумне!

Давайте работы! Мне каждое дело

Легко и привычно, пока

Смотрю я на светлую будущность смело Рабочей семьи бедняка ${ }^{24}$.

Мы видим, как Дрожжин с большим трудом пытается решить сложнейшую для себя (и вообще для общественного сознания) тему - желание человека трудиться во имя родной страны, невзирая на свое униженное и угнетенное положение и в надежде на некую «светлую будущность». В ранней редакции эта тема осложняется готовностью воевать (в случае необходимости) за родину, основная тема сформулирована в призыве «Давайте работать!». Но потом это осложнение уходит, и остается только просьба «Давайте работы!». Если нам дадут работать - мы всё совершим, всё преодолеем, только дайте нам возможность работать. Эта просьба появляется «под впечатлением долгого скитальчества, голодания и безработицы». Рабочему человеку нет работы - вот главная проблема. Но в сознании Дрожжина она так и не выдвигается на первый план, и всё сводится к просьбе «Давайте работы!». Дрожжин, как, впрочем, и другие народные поэты, не поднимается до осмысления истинных причин своих истинных бед. «Светлой будущности <...> рабочей семьи бедняка» не видно, но поэт тешит себя этой несбыточной надеждой.

Весьма показательны и изменения, которым подверглось стихотворение «Застольная песня», посвященная П.А. Соловьеву-Несмелову. Первоначально текст выглядел следующим образом:

Наша жизнь коротка, -

Веселися, пока

Еще сердце горячее бьется,

Пока мозг не иссох

24 Поэзия труда и горя: Новое собрание стихотворений С.Д. Дрожжина с портретом автора и указателем статей о его произведениях, составленных И. Горбуновым-Посадовым. М.: Тип. Т-ва И.Д. Сытина, 1901. С. 100. 
И последний твой вздох

Вместе с жизнью твоей не порвется.

А для Руси святой

Ты за правду постой

И во имя ученья Христова

Силой братской любви

Для нее оживи

Как огонь вдохновенное слово 25 .

Но к новому изданию, которое Дрожжин готовил в 1920 г., финал требовал изменения:
Наша жизнь коротка, -
Веселися, пока
Еще сердце горячее бьется,
Пока мозг не иссох
И последний твой вздох
Вместе с жизнью твоей не порвется.
За народ свой родной
И за правду постой,
Будь на всякие жертвы готовый.
В песне силой любви
Из души оживи
Как огонь вдохновенное слово (л. 32).

Разумеется, вся эта фразеология: «Русь святая», «ученье Христово», «братская любовь» - в эпоху антицаристских и антицерковных настроений, в эпоху классовой ненависти была более чем неуместна. В это время ценилась жертвенность во имя народа («Вы жертвою пали в борьбе роковой») - и Дрожжин переориентирует стихотворение на эти пролетарские ценности. Значит ли это, что нам придется говорить о конформизме Дрожжина?

Как можно заметить, для революционно настроенного сознания выражения «Русь святая», «ученье Христово», «братская любовь» антонимичны выражению «за народ свой родной / И за правду постой, / Будь на всякие жертвы готовый». Но вообще-то (и, как мы понимаем, Дрожжин руководствовался именно этой позицией) слова «за народ свой родной / И за правду постой, / Будь на всякие жертвы готовый» не противопоставлены словам «Русь святая», «ученье Христово», «братская любовь», не антонимичны им, а являются их

\footnotetext{
${ }^{25}$ Дрожжин С.Д. Собрание сочинений. Т. 1. С. 155.
} 
синонимами. Так что Дрожжин не лицемерил и не изменял своим взглядам, он просто смягчал некоторые выражения. Он, что называется, не дразнил быка и пытался найти с ним общий язык.

Дрожжин, конечно, на самом деле был склонен ко всяким компромиссам, но было бы большой ошибкой воспринимать это как особенность его личного сознания и общественного поведения. Склонность к компромиссам - это свойство личного сознания и общественного поведения народной массы вообще, и мы непременно должны учитывать это, чтобы адекватно осмыслить отличия «народной» литературы от «интеллигентской». Для «интеллигентских» авторов такую позицию мы назвали конформизмом, для народных авторов термин конформизм определенно не подходит. Здесь требуется более тонкий идеологический инструментарий, чем тот, который мы применяем к более привычной нам «интеллектуальной» поэзии.

\section{Литература}

Дрожжин С.Д. Гусляр: Неопубликованные произведения / Предисл., подгот. текста и примеч. Е.В. Павловой, М.В. Строганова. М.: РГУ им. А.Н. Косыгина, 2018. $412 \mathrm{c}$.

Дрожжин С.Д. Собрание сочинений: В 3 т. / Подгот. текстов Е.В. Павловой, Е.В. Петренко, М.В. Строганова; Примеч. Е.В. Петренко, М.В. Строганова; Предисл. Е.В. Павловой, М.В. Строганова. Тверь: СФК-офис, 2015. 360, 328, 432 с.

Строганов М.В. Рафинированное и простонародное. Рильке и Андреас-Саломе в гостях у Дрожжина // Лабиринт: журнал социально-гуманитарных исследований. 2016. № 3/4. C. 71-85. URL: http://journal-labirint.com/wp-content/uploads/2016/09/ Stroganov.pdf (дата обращения: 21.11.2019).

\section{References}

Drozhzhin S.D. Gusliar: Neopublikovannye proizvedeniia [Gusli player: Unpublished works], intro., ed. and notes E.V. Pavlova, M.V. Stroganov. Moscow, Kosygin Russian State University Publ., 2018. 412 p. (In Russ.)

Drozhzhin S.D. Sobranie sochinenii: V 3 t. [Collected works: In 3 vols.], ed. E.V. Pavlova, E.V. Petrenko, M.V. Stroganov, notes E.V. Petrenko, M.V. Stroganov, intro. E.V. Pavlova, M.V. Stroganov. Tver, SFK-ofis Publ., 2015. 360, 328, 432 p. (In Russ.)

Stroganov M.V. Rafinirovannoe i prostonarodnoe. Ril'ke i Andreas-Salome v gostiakh u Drozhzhina [Refined and folksy: Rilke and Andreas-Salomé meeting Drozhzhin]. Labirint: zhurnal sotsial'no-gumanitarnykh issledovanii [Electronic resource], 2016, no. $3 / 4$, pp. 71-85. Available at: http://journal-labirint.com/wp-content/uploads/2016/09/ Stroganov.pdf (accessed: 21.11.2019). (In Russ.) 


\title{
New materials on life and work of Spiridon Drozhzhin. Issues of studying a folk poet
}

\author{
(C) 2019, Mikhail Stroganov
}

\begin{abstract}
The article analyzes the 1920 project of publishing a new collection of poems by Spiridon Drozhzhin, Russian peasant poet of the late $19^{\text {th }}$ - early $20^{\text {th }}$ centuries, who still attracts little attention of researchers. As the analysis establishes, the manuscript from the Memorial Museum of Spiridon Drozhzhin in the urbantype settlement Novozavidovsky contains a list of poems with commentaries of a contextual, textual and bibliographic nature, which allow to supplement the existing information about Drozhzhin's life and work, including names of the recipients of his love lyrics. The source is introduced into scientific circulation for the first time, thereby clarifying some key points related to the studying of "folk poets" in Russian literature. A detailed list of texts included in the manuscript is given in the article. Clarification of dedications and datings restores important points in the poet's biography. Comparison of text variants for some of Drozhzhin's poems, created in different years, raises the issue of qualification of these changes. In contrast to conformism, as we usually qualify the reconciliatory positions of "intellectual" literature, it is proposed to call this phenomenon a tendency to compromise, which reflected the public behavior of the masses due to the low level of intellectual development and the inability to comprehend the true causes of the phenomena.
\end{abstract}

Keywords: Spiridon Drozhzhin, folk poet, textology, commentary, textual variants

Information about the author: Mikhail Stroganov, Dr Hab, Leading Research Associate, Institute of World Literature of the RAS, Moscow, Russia. E-mail: mvstroganov@gmail.com

Citation: Stroganov Mikhail. New materials on life and work of Spiridon Drozhzhin. Issues of studying a folk poet. Literaturnyi fakt, 2019, no 4 (14), pp. 314 332. DOI 10.22455/2541-8297-2019-14-314-332 